\title{
Morphological, Mineralogical, and Physico-Chemical Characteristics of Some Dark Clay Soils of Puerto Rico ${ }^{1}$
}

\author{
Gilberto Acevedo, G. W. Kunze, and M. A. Lugo-Lopez ${ }^{2}$
}

\begin{abstract}
Morphological studies of some of the dark clay soils of Puerto Rico indicate that they are similar to the black or dark soils of the Tropics and of other areas now mostly classified as Vertisols and some as Mollisols. They are clayey with high saturation and porosity. Small pores predominate, however, resulting in low hydraulic conductivity and poor internal drainage. They are alkaline, soil $\mathrm{pH}$ increasing with depth. Organic matter is generally high in the surface horizons. Quartz is the dominant mineral in the silt fraction, but lesser amounts of feldspars are present in all the soils. Montmorillonite is the dominant clay mineral with kaolinite and quartz occurring in trace to small amounts. Montmorillonite and kaolinite, in some profiles, showed a greater degree of crystallinity by their more symmetrical diffraction peaks. X-ray diffraction results for the Aguirre and Guánica soils were indicative of a minimum amount of weathering. The clay minerals in the surface horizon of the Ponceña and Camagüey soils showed a small amount of weathering. The data available indicate that the dark clay soils of Puerto Rico meet many of the requirements of the Pellusterts, Pelluderts, and Rendoll soil groups.
\end{abstract}

\section{INTRODUCTION}

Puerto Rico is a tropical island with a wide range of rainfall, an assortment of parent materials, and variable geomorphic situations that have given rise to different soils within relatively small distances (10). Some of them are black or dark clayey soils which are similar to those previously known as rendzina (southern United States), regur (India), black cotton soils (Africa), and tirs (Morocco). For some of them the name Grumusol was previously used. They are now classified, according to the U.S. Soil Taxonomy, mostly as Vertisols and some as Mollisols (14). In an attempt to relate some of the soils of Puerto Rico to this group

${ }^{1}$ Manuscript submitted to Editorial Board June 4, 1975.

${ }^{2}$ Former Research Assistant, now Soil Scientist, USDA Soil Conservation Service, Professor of Soil Mineralogy and Dean of the Graduate College, Texas A and M University, and Professor and Soil Scientist, University of Puerto Rico, Mayagüez Campus, Agricultural Experiment Station, Río Piedras, P.R. 
of tropical black or dark soils, selected profiles were studied. Emphasis was given to the characterization of the morphological, physico-chemical and mineralogical properties of the complete profiles. This was done to gain a better understanding of the interrelationships among these darkcolored soils both from the viewpoint of soil classification and future agricultural development.

\section{MATERIALS AND METHODS}

The profile sites were as follows: Aguirre clay, El Anegado in the Lajas Valley; Guánica clay, recently drained Guánica Lagoon, north of the main drainage canal, Lajas Valley; Ponceña clay, road 114, km 124.6, Ponce; Santa Clara clay, road 111, km 3.2, Moca; Camagüey clay, road 111, $\mathrm{km} \mathrm{4.3,} \mathrm{Moca.} \mathrm{Profile} \mathrm{descriptions} \mathrm{were} \mathrm{written} \mathrm{according} \mathrm{to}$ standard USDA procedures (16). The Ponceña profile was taken from a cultivated area, while the other four came from virgin areas. Only one representative profile of each series was studied. To insure a proper morphological study of the profiles and to facilitate the sampling, a pit was dug 4 feet wide, 4 feet long, and as deep as required to reach the parent material.

Undisturbed soil cores ( $3 \times 3$ inches) were taken from the different soil profile layers with an Uhland ${ }^{3}$ sampler for physical determinations.

Hydraulic conductivity determinations were made by measuring the rate at which water was moved through a column of soil by a known head of water. Soil cores were saturated with water after air was removed by placing the cores in a desiccator and applying a vacuum. Hydraulic conductivity values were calculated according to the method outlined in USDA Agricultural Handbook No. 60 (17).

Quick drainage was determined by placing the saturated soil cores in Buchner funnels at $60 \mathrm{~cm}$ of tension and measuring the amount of water that drained in 15 minutes. Quick drainage is expressed as a percentage, which is obtained by dividing the volume of water drained by the volume of the soil and multiplying by 100 .

The saturated soil cores were then placed on a $60 \mathrm{~cm}$-tension table until equilibrium was attained. The water retained by the soil at this tension was expressed as a $\mathrm{pF}$ value for the $60 \mathrm{~cm}$ tension. The cores were dried at $110^{\circ} \mathrm{C}$ and weighed. As the original volume of the cylinder was known, bulk density of the soil was calculated by dividing the weight of the soil by its volume. Pore space was then calculated.

\footnotetext{
${ }^{3}$ Trade names are used in this publication solely for the purpose of providing specific information. Mention of trade names does not constitute a guarantee or warranty of the equipment by the Agricultural Experiment Station of the University of Puerto Rico or an endorsement over other equipment not mentioned.
} 
Silt and clay samples were prepared for X-ray diffraction analysis according to procedures described in earlier publications $(7,8,9)$.

For differential thermal analysis the clay fraction $(<2 \mu)$ was saturated with magnesium using a magnesium acetate solution at $\mathrm{pH}$ 7. Approximately $1.5 \mathrm{~g}$ of clay was placed in a $100 \mathrm{ml}$ centrifuge tube, $40 \mathrm{ml}$ of 1.0 $N$ magnesium acetate added and shaken for 5 minutes. The sample was then centrifuged and the supernatant liquid decanted. The magnesium acetate treatment was repeated 3 times, after which the sample was washed with 20 to $25 \mathrm{ml}$ portions of $95 \%$ ethyl alcohol until the conductivity of the supernatant liquid was too low to be read on the conductivity bridge (Model R-26, Industrial Instruments). Following the last alcohol washing the sample was dried at $65^{\circ} \mathrm{C}$ and ground to pass a 60 -mesh sieve. The dry clay sample was placed in a desiccator containing a slurry of magnesium nitrate and allowed to come to equilibrium with the atmosphere ( 55 to $60 \%$ relative humidity at $25^{\circ} \mathrm{C}$ ), after which it was ready to be analyzed.

The X-ray diffraction unit used was a North American Phillips high-angle goniometer model equipped with a copper target tube.

Cation exchange capacity for the soil was determined according to Method 19 of USDA Agricultural Handbook No. 60 (17). Soluble salts were removed prior to the analysis. Calcium carbonate was removed from the samples and the cation exchange capacity was again determined as outlined above. Calcium carbonate content was determined on the basis of acid neutralization according to Method 23C of Agricultural Handbook No. 60 (17). The exchangeable cations were displaced with $1.0 \mathrm{~N}$ ammonium acetate and determined with a Beckman Model DU flame photometer.

Organic matter was determined according to the wet oxidation method proposed by Peech et al. (12). The $\mathrm{pH}$ was determined on a 1:2 soil water paste which was allowed to stand for one hour prior to taking the reading.

\section{RESULTS}

\section{MORPHOLOGICAL PROPERTIES}

The Aguirre and Guánica clay soils, developed from calcareous parent material, occur in the valleys of the arid and semiarid region. They are characterized by a dark-colored, plastic, sticky, alkaline clay. The soil structure is moderately developed in the surface horizon and becomes weaker with depth. The soils have a highly expansive type of clay mineral which causes them to crack upon drying. Soil reaction is alkaline and gypsum crystals are found at the lower depths. These soils become waterlogged after heavy rainfall due to poor drainage.

The Santa Clara and Camaguiey clay soils occur in the humid section 
of the soft limestone belt. They occupy low undulating hills. The surface horizons are characterized by a black or dark-colored, plastic, calcareous clay. Soil structure is moderately developed in the surface horizons but becomes weaker with depth. These soils are sticky when wet and crack upon drying. They have good surface drainage since they occupy the slopes, as contrasted to the Aguirre and Guánica clays which occupy low, nearly level lands. The Santa Clara and Camagüey soils are alkaline in reaction, and limestone fragments are found throughout the profile. The parent materials of these soils are calcareous as are those of the Aguirre and Guánica clay soils.

Areas of Ponceña clay, in the southern part of the island, are characterized by a black clay in the surface. This soil, like those previously described, becomes plastic and sticky when wet and cracks upon drying. Large lime concretions are present at the lower depths of the profile. The parent material is calcareous.

In general, all five soils are characterized by a black or dark-colored, plastic clay in the surface. The soil structure is moderately developed in the surface and becomes weaker at lower depths. The soils crack upon drying and become sticky when wet. They are difficult to plow under wet conditions. The parent materials are calcareous and lime concretions are generally found throughout the profiles. Gypsum may be found at the lower depths of the Aguirre and Guánica clay.

The morphological data obtained in this study describe some of the soils of Puerto Rico that tend to be similar to the black or dark-colored soils of the tropics and other soils of the world, including the soils of India (Regur), Morocco (Tirs), Africa (Black Cotton Soils), and the southern United States (Rendzina) previously known as Grumusols, Chestnut, Chernozem, Brunizems, Rendzinas, and others $(1,4,13,15,18,19)$. These soils according to the new soil classification scheme, are now classified as Vertisols and Mollisols.

PHYSICAL PROPERTIES

The physical properties of the soil profiles are presented in table 1 . The hydraulic conductivity is low to very low, except for the 0-3 in. and 3-12 in. horizons of the Aguirre profile and the 39-63 in. horizon of the Ponceña profile. Structural conditions seem to be responsible for this difference. In the Aguirre clay soil these high values may be due to the presence of cracks and coarse to medium size pores, while in the Ponceña clay the presence of many coarse concretions may have some effect on the rate of water movement through the soil. Although the relationship of porosity and the rate of water movement is not well understood, it is known that the content of large pores is the important factor in water movement through the soil. Proportion of large pores, soil texture, volume changes, 
TABLE 1,-Physical properties for five soil profiles of dark clay soils of Puerto Rico

\begin{tabular}{|c|c|c|c|c|c|c|c|}
\hline Soil type & Depth & $\begin{array}{l}\text { Hydraulic } \\
\text { conductivity }\end{array}$ & $\begin{array}{c}\text { Quick } \\
\text { drainage }\end{array}$ & $\begin{array}{c}\text { Bulk } \\
\text { density }\end{array}$ & Porosity & $\begin{array}{l}\text { Maximum } \\
\text { saturation }\end{array}$ & $\begin{array}{l}\text { Water } \\
\text { retained } \\
\text { pF } 1.78\end{array}$ \\
\hline & In & $\operatorname{In} / \mathrm{hr}$ & $\%$ & $G / \mathrm{cm}^{3}$ & & $\%$ & $\begin{array}{c}\% \\
\text { by volume }\end{array}$ \\
\hline \multirow[t]{5}{*}{ Aguirre clay } & $0-3$ & 6.24 & 6.3 & 0.88 & 66.5 & 71.4 & 66.1 \\
\hline & $3-12$ & 1.75 & 2.1 & 1.00 & 63.0 & 70.2 & 66.0 \\
\hline & $12-32$ & .03 & .5 & 1.17 & 55.8 & 69.1 & 66.7 \\
\hline & $38-60$ & .03 & .7 & 1.10 & 55.8 & 69.5 & 66.9 \\
\hline & $60-72$ & .06 & 1.6 & 1.08 & 56.4 & 71.0 & 66.0 \\
\hline \multirow[t]{6}{*}{ Guánica clay } & $0-9$ & .26 & 1.5 & 1.04 & 60.6 & 64.7 & 59.1 \\
\hline & $9-18$ & .01 & 3.4 & 1.02 & 61.3 & 60.3 & 58.7 \\
\hline & $18-33$ & .05 & 2.6 & 1.01 & 61.9 & 64.1 & 62.6 \\
\hline & $33-45$ & .005 & 3.8 & 1.07 & 59.4 & 62.9 & 60.9 \\
\hline & $45-60$ & .005 & 3.6 & 1.15 & 56.5 & 59.3 & 57.2 \\
\hline & $60-70$ & .05 & 5.5 & 1.14 & 56.9 & 61.0 & 59.3 \\
\hline \multirow[t]{4}{*}{ Ponceña clay } & $0-12$ & .50 & 2.9 & 1.17 & 56.0 & 36.5 & 54.0 \\
\hline & $16-25$ & .24 & 2.2 & 1.16 & 56.1 & 39.3 & 57.5 \\
\hline & $25-34$ & .91 & 2.6 & 1.36 & 48.7 & 50.7 & 49.6 \\
\hline & $39-63$ & 2.16 & 3.6 & 1.38 & 48.1 & 49.2 & 47.3 \\
\hline \multirow[t]{5}{*}{ Santa Clara clay } & $0-16$ & .005 & .7 & .99 & 62.7 & 59.7 & 56.5 \\
\hline & $16-28$ & .005 & 3.5 & 1.34 & 49.6 & 48.1 & 46.5 \\
\hline & $28+1$ & .02 & .7 & 1.22 & 54.2 & 58.7 & 57.8 \\
\hline & $41-51$ & .02 & .9 & 1.46 & 44.9 & $4 \pi .0$ & 43.9 \\
\hline & +51 & .005 & .5 & 1.33 & 49.8 & 51.1 & 50.3 \\
\hline \multirow[t]{6}{*}{ Camagüey clay } & 015 & .63 & 1.8 & 1.37 & 48.2 & 50.0 & 47.2 \\
\hline & $15-28$ & $.00 i$ & 2.9 & 1.23 & 53.6 & 54.9 & 53.9 \\
\hline & $28-42$ & .005 & .7 & 1.38 & 47.8 & 47.0 & 46.8 \\
\hline & $42-56$ & .03 & 1.3 & 1.30 & 51.0 & 53.2 & 52.2 \\
\hline & $56-64$ & .07 & 1.3 & 1.20 & 54.6 & 54.2 & 52.9 \\
\hline & +64 & .05 & .9 & 1.27 & 52.3 & 53.7 & 52.4 \\
\hline
\end{tabular}

biological channels, and saturation of the pores are among the factors which influence the rate of water movement through the soil. These data show that water movement in these soils is relatively restricted and indicate the problems that would be encountered in a drainage and reclamation project involving these soils.

The values obtained for quick drainage (table 1) are relatively low. The highest value obtained was in the top horizon of the Aguirre profile, which is highly aggregated in the surface. Bulk density values range from $0.88 \mathrm{~g} / \mathrm{cm}^{3}$ in the surface horizon of the Aguirre profile to $1.46 \mathrm{~g} / \mathrm{cm}^{3}$ in the 41-51 in. horizon of the Santa Clara profile. If the entire profile is considered, bulk densities for the Aguirre and Guánica profiles are the 
lowest. These lower bulk densities are indicative of a higher porosity and greater water holding capacity, which is corroborated by the data in table 1.

The particle size distribution data reported in table 2, show the clayey character of all the soils. It is interesting to note that the Santa Clara profile has the highest content of sand, ranging from $16.1 \%\left(28-41^{\prime \prime}\right)$ to $42.3 \%$ (16-28 in.) while the Guánica profile contains the lowest amount which ranges from $2.1 \%$ ( $45-60$ in.) up to $4.4 \%$ (0-9 in.). The lowest average clay content is found in the Santa Clara soil (46.1\%), and in this soil the content of sand exceeds the content of silt in all the horizons except

TABle 2.-Particle size distribution in five profiles of dark clay soils of Puerto Rico

\begin{tabular}{|c|c|c|c|c|}
\hline Soil type & Depth & Sand & Silt & Clay \\
\hline & $\ln$ & & $\%$ & \\
\hline \multirow[t]{6}{*}{ Aguirre clay } & $0-3$ & 5.5 & 31.5 & 63.0 \\
\hline & $3-12$ & 12.1 & 21.9 & 66.0 \\
\hline & $12-32$ & 9.5 & 23.5 & 67.0 \\
\hline & $32-38$ & 7.9 & 25.8 & 66.7 \\
\hline & $38-60$ & 9.0 & 28.8 & 62.2 \\
\hline & $60-72$ & 5.5 & 35.4 & 59.1 \\
\hline \multirow[t]{6}{*}{ Guánica clay } & $0-9$ & 4.4 & 43.5 & 52.1 \\
\hline & $9-18$ & 2.3 & 38.4 & 59.3 \\
\hline & $18-33$ & 2.4 & 36.7 & 60.9 \\
\hline & $33-45$ & 2.3 & 31.5 & 66.2 \\
\hline & $45-60$ & 2.1 & 26.2 & 71.7 \\
\hline & $60-70$ & 2.4 & 27.3 & 70.3 \\
\hline \multirow[t]{5}{*}{ Poncena clay } & $0-12$ & 9.8 & 31.4 & 58.8 \\
\hline & $12-16$ & 5.9 & 26.3 & 67.8 \\
\hline & $16-34$ & 5.5 & 30.1 & 64.4 \\
\hline & $34-39$ & 4.2 & 32.3 & 63.5 \\
\hline & $39-63$ & 5.9 & 36.2 & 57.9 \\
\hline \multirow[t]{5}{*}{ Sania (luara clay } & $0-16$ & 32.3 & 24.2 & 43.5 \\
\hline & $16-28$ & 42.3 & 20.3 & 37.4 \\
\hline & $28-41$ & 16.1 & 27.1 & 56.8 \\
\hline & $41-51$ & 38.1 & 19.6 & 42.3 \\
\hline & +51 & 25.5 & 23.9 & 50.6 \\
\hline \multirow[t]{7}{*}{ Camaguey clay } & $0-15$ & 24.3 & 29.6 & 46.1 \\
\hline & $15-28$ & 23.5 & 30.6 & 45.9 \\
\hline & $28-31$ & 10.5 & 30.5 & 59.0 \\
\hline & $31-42$ & 20.6 & 28.0 & 51.4 \\
\hline & $42-56$ & 5.3 & 28.2 & 66.5 \\
\hline & $56-6 t$ & 6.4 & 23.8 & 69.8 \\
\hline & +64 & 2.8 & 31.0 & 66.2 \\
\hline
\end{tabular}


in the 28-41 in. horizon. For the other four profiles the silt content exceeds the sand content. The Aguirre, Guánica, Ponceña, and Camagüey profiles show approximately the same average clay content, ranging from $57.8 \%$ in the Camaguiey soil to $64.0 \%$ in the Aguirre.

In general, it was found that the soils have a low hydraulic conductivity and quick drainage but have a high porosity and high clay content. Small pores dominate the soil as shown by the high water holding capacity at low tensions.

\section{CHEMICAL PROPERTIES}

Chemical data are presented in table 3. The $\mathrm{pH}$ ranged from 6.0 in the surface horizon of the Ponceña profile to 8.6 in the deepest horizons of the Aguirre profile. The comparatively low $\mathrm{pH}$ for the Ponceña soil is probably due to the effect of organic matter along with a relatively low content of exchangeable sodium and magnesium plus the absence of any free calcium carbonate. The $\mathrm{pH}$ increased with depth in all the profiles.

Free calcium carbonate was found in all horizons of all the profiles, except in the first two horizons of the Ponceña profile. Much of it occurred in the form of lime concretions and lime fragments. The highest amount $(52.6 \%)$ was found in the 54-64 in. horizon of the Camaguiey profile.

The organic matter content of the surface horizons for all profiles is high considering that the soils are from a tropical area. The Aguirre and Guánica soils are waterlogged during some part of the year, as a consequence of poor surface and internal drainage, which makes possible the accumulation of the relatively high amounts (up to $11.0 \%$ ) of organic matter. In the Ponceña, Santa Clara, and Camagüey profiles the major portion of the organic matter occurs in the surface horizon. The abundant vegetative growth on these soils is thought to be responsible for this condition. The high clay content, plus the type of clay (montmorillonitic) is also thought to be an important consideration in explaining the high organic matter content of these soils. It is generally accepted that decomposition of humus by biological means is difficult when adsorbed by clay minerals. In all of the profiles studied, organic matter content decreased with depth.

Cation exchange capacity values are quite variable within any profile, as shown in table 3. The Aguirre and Guánica profiles show the highest exchange capacities both on the untreated and calcium carbonate-free basis.

The results for exchangeable cations show that the Aguirre and Guánica profiles contain relatively large amounts of exchangeable sodium and magnesium. The sodium content increased with depth in both profiles. Due to the limited amount of sample that was available, 
TABLE 3.-Chemical properties for five soil profiles of dark clay soils of Puerto Rico

\begin{tabular}{|c|c|c|c|c|c|c|c|c|c|c|}
\hline \multirow{2}{*}{ Soil type } & \multirow{2}{*}{ Depth } & \multirow{2}{*}{$\mathrm{pH}$} & \multirow{2}{*}{$\begin{array}{l}\text { Organic } \\
\text { matter }\end{array}$} & \multirow{2}{*}{$\begin{array}{l}\text { Calcium } \\
\text { carbonate } \\
\text { equivalent }\end{array}$} & \multicolumn{2}{|c|}{$\begin{array}{l}\text { Cation exchange } \\
\text { capacity }\end{array}$} & \multicolumn{4}{|c|}{ Exchangeable cations } \\
\hline & & & & & $\begin{array}{c}\text { Un- } \\
\text { treated }\end{array}$ & $\begin{array}{l}\mathrm{CaCO}_{3} \\
\text { free }\end{array}$ & $\mathrm{Ca}$ & $\mathrm{Na}$ & $\mathrm{Mg}$ & $\mathrm{K}$ \\
\hline & \multicolumn{2}{|l|}{ In } & \multicolumn{2}{|r|}{$\%$} & \multicolumn{2}{|c|}{ Meq/100g soil } & \multicolumn{4}{|c|}{$\mathrm{Meq} / 100 \mathrm{~g}$ soil } \\
\hline \multirow[t]{6}{*}{ Aguirte clay } & $0-3$ & 7.2 & 11.0 & 6.6 & 94.9 & 91.3 & Calc. & 1.7 & 26.6 & 3.5 \\
\hline & $3 \cdot 12$ & 7.7 & 8.3 & 6.9 & 116.9 & 100.3 & " & 5.7 & 39.6 & 1.2 \\
\hline & $12-32$ & 8.3 & 3.5 & 17.1 & 86.1 & 94.1 & “ & 14.8 & 51.4 & .8 \\
\hline & $32-38$ & 8.5 & 2.0 & 16.5 & 79.13 & 85.9 & “ & 27.5 & 46.7 & 1.0 \\
\hline & $38-60$ & 8.6 & 1.1 & 17.2 & 74.4 & 79.6 & Gyp. & 31.1 & 38.3 & 1.0 \\
\hline & $60-72$ & 8.6 & .6 & 20.7 & 60.1 & 66.3 & " & 28.9 & 31.3 & 1.1 \\
\hline \multirow[t]{6}{*}{ Guánica clay } & $0-9$ & 7.6 & 4.6 & 10.9 & 65.2 & 74.6 & Calc. & 4.8 & 35.4 & 1.8 \\
\hline & $9-18$ & 7.8 & 2.0 & 9.7 & 69.5 & 75.1 & " & 8.3 & 33.9 & 1.4 \\
\hline & $18-33$ & 7.9 & 1.7 & 11.9 & 64.9 & 75.8 & “ & 12.1 & 32.8 & 1.4 \\
\hline & $33-45$ & 7.9 & 1.2 & 13.9 & $6: 3.3$ & 73.8 & "، & 17.3 & 29.4 & 1.4 \\
\hline & $45-60$ & 7.9 & .4 & 13.9 & 59.8 & 64.3 & Gyp. & 19.2 & 22.6 & 1.4 \\
\hline & $60-70$ & 8.0 & .3 & 13.5 & 56.6 & 65.8 & “ & 23.7 & 25.6 & 1.6 \\
\hline \multirow[t]{5}{*}{ Ponceña clay } & $0-12$ & 6.0 & 4.5 & - & 60.4 & 一 & - & .6 & 7.2 & .6 \\
\hline & $12 \cdot 16$ & 7.6 & 2.0 & - & 62.4 & - & - & .7 & 7.6 & .6 \\
\hline & $16-34$ & 7.7 & 1.1 & 5.7 & 59.9 & 55.5 & Calc. & .9 & 6.4 & .5 \\
\hline & 3439 & 7.8 & .7 & 23.6 & 35.1 & 54.0 & $"$ & .6 & 3.5 & .3 \\
\hline & $39-63$ & 7.9 & .4 & 23.1 & 32.0 & 53.6 & ، & .9 & 4.3 & .4 \\
\hline \multirow{5}{*}{$\begin{array}{l}\text { Santa Clara } \\
\text { clay }\end{array}$} & $0-16$ & 7.4 & 4.7 & 12.4 & 40.8 & 42.6 & Calc. & .3 & 1.2 & .3 \\
\hline & 1628 & 7.7 & 1.0 & 23.7 & 27.1 & 33.2 & “" & .3 & .7 & .2 \\
\hline & 2841 & 7.6 & 2.1 & 8.8 & 55.2 & 53.3 & “ & .4 & 1.0 & .3 \\
\hline & $41-51$ & 7.7 & .7 & 29.4 & 26.9 & 32.2 & “ & .4 & .9 & .3 \\
\hline & +51 & 7.7 & .8 & 20.1 & 37.7 & 42.6 & “ & .4 & 1.1 & .3 \\
\hline \multirow[t]{7}{*}{ Camagüey clay } & $0-15$ & 7.5 & 4.9 & 19.6 & 38.0 & 45.9 & Calc. & .3 & 1.6 & .3 \\
\hline & $15-28$ & 7.7 & 1.0 & 23.4 & 27.5 & 34.6 & " & .3 & .7 & .3 \\
\hline & $28-31$ & 7.7 & 1.3 & 12.8 & 47.0 & 57.9 & “" & .4 & 1.1 & .4 \\
\hline & $31-42$ & 7.7 & .8 & 24.6 & 34.6 & 43.6 & “ & .3 & .9 & .4 \\
\hline & $42-56$ & 7.8 & 1.0 & 35.8 & 38.1 & 64.0 & " & .4 & 1.2 & .4 \\
\hline & $56-64$ & 7.8 & 1.3 & 32.6 & 35.8 & 77.0 & ، & .3 & 1.1 & .4 \\
\hline & +64 & 7.8 & .8 & 29.9 & 41.3 & 57.7 & ، & .3 & 1.6 & .3 \\
\hline
\end{tabular}

water-soluble cations were not determined, which might conceivably have reduced these values considerably. The abundance of cations undoubtedly influences the physical properties of these profiles, such as plasticity, high water holding capacity, and high coefficient of expansion, The high rainfall supplemented by good drainage is thought to be responsible for the relatively low content of exchangeable sodium, magnesium, and potassium in the Santa Clara and Camagüey profiles, The Ponceña soil is also well drained. In contrast, the Aguirre and 
Guánica soils are poorly drained and are waterlogged for several months of the year, which seems to be responsible, at least in part, for the higher exchangeable sodium and magnesium contents of these soils.

Exchangeable calcium was not determined because calcium carbonate and/or gypsum occurred in all but two horizons.

\section{MINERALOGICAL PROPERTIES}

$\mathrm{X}$-ray diffraction studies of the silt fraction showed it to be dominated by quartz. Lesser amounts of feldspars were present in all the profiles and in all the horizons.

Figure 1 presents $\mathrm{X}$-ray diffraction patterns of 2-micron fractions for the Aguirre and Guánica profiles. Montmorillonite (17.0 to $18.0 \AA$ ) is the

$$
\text { X-ray Diffraction Patterns }
$$
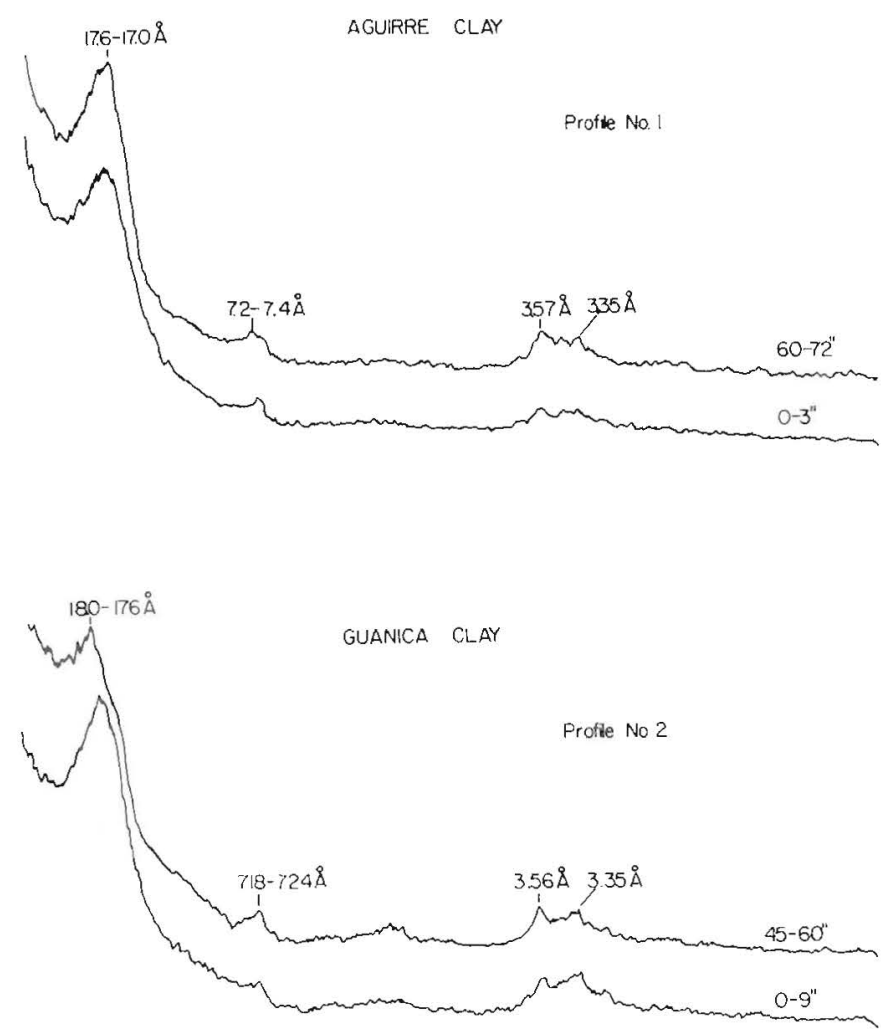

FiG. 1.-X-Ray diffraction pattern of the $<2$-micron fraction of the Aguirre and Guánica profiles. 
dominating clay mineral, with lesser amounts of kaolinite (7.16 to $7.4 \AA$, 3.56 to $3.57 \AA$ ) and quartz $(3.35 \AA)$. Such characteristics as plasticity, cracking upon drying, high swelling, and high exchange capacity of these profiles are closely related to the montmorillonitic type of clay mineral.

The equally intense and symmetrical (001) peaks for montmorillonite, in the surface and the deepest samples of the Aguirre and Guánica profiles, are interpreted to be indicative of an approximately equal degree of weathering. Since there is no apparent difference in the degree of weathering between the top and deepest horizons, the soils are considered to have undergone a minimum of weathering.

Montmorillonite ( 17.0 to $17.60 \AA$ ) also dominates the clay fraction of the Ponceña, Santa Clara, and Camagüey profiles, as shown in figure 2. The amount of kaolinite ( 7.31 to $7.4 \AA, 3.57 \AA$ ) present is greater than in the Aguirre and Guánica profiles. Only a trace of quartz was present as shown by the X-ray diffraction patterns. All the patterns within the same profile were run at the same intensity. The X-ray diffraction patterns of the Ponceña, Santa Clara, and Camagüey profiles, indicate that montmorillonite and kaolinite have a greater degree of crystallinity as shown by the more symmetrical peaks. However, the deeper horizons show a slightly sharper and more intense peak than the surface horizons, indicating some degree of weathering of the clay in the surface. X-ray diffraction studies of the clay fraction of the Lufkin soil, a type of clay pan (Vertic Albaqualf) from Texas, showed more pronounced weathering between the A horizon and the deepest horizon (8), as compared to the last three profiles studied from Puerto Rico.

In general, on the basis of X-ray diffraction studies, montmorillonite is the predominant clay mineral in all the profiles, with kaolinite and quartz occurring in trace to small amounts. In the Aguirre and Guánica soils the crystallinity of montmorillonite is poorer than that of the other soils as evidenced by the X-ray diffraction patterns. The clay fraction in all the profiles shows a minimal degree of weathering. In the Ponceña, Santa Clara, and Camagüey soils, kaolinite appears to make up a large percentage of clay fraction. This is also supported by the values obtained for the exchange-capacity determinations.

Differential thermal analyses (D.T.A.) for the 2-micron fraction are presented in figures 3 and 4. Aguirre (Profile No. 1) and Guánica (Profile No. 2) show an initial endothermic peak at a temperature between $150^{\circ}$ and $160^{\circ} \mathrm{C}$, and indications of a very weak endothermic peak at a temperature between $180^{\circ}$ and $190^{\circ} \mathrm{C}$. A broad and shallow endotherm occurs at a temperature of $565^{\circ}$ to $570^{\circ} \mathrm{C}$. The first endothermic peak can be attributed to the loss of the interlayer water by montmorillonite, while the second endothermic peak $\left(565^{\circ}\right.$ to $\left.570^{\circ} \mathrm{C}\right)$ is probably due to the loss of $(\mathrm{OH})$ water from kaolinite and montmorillonite. The presence 

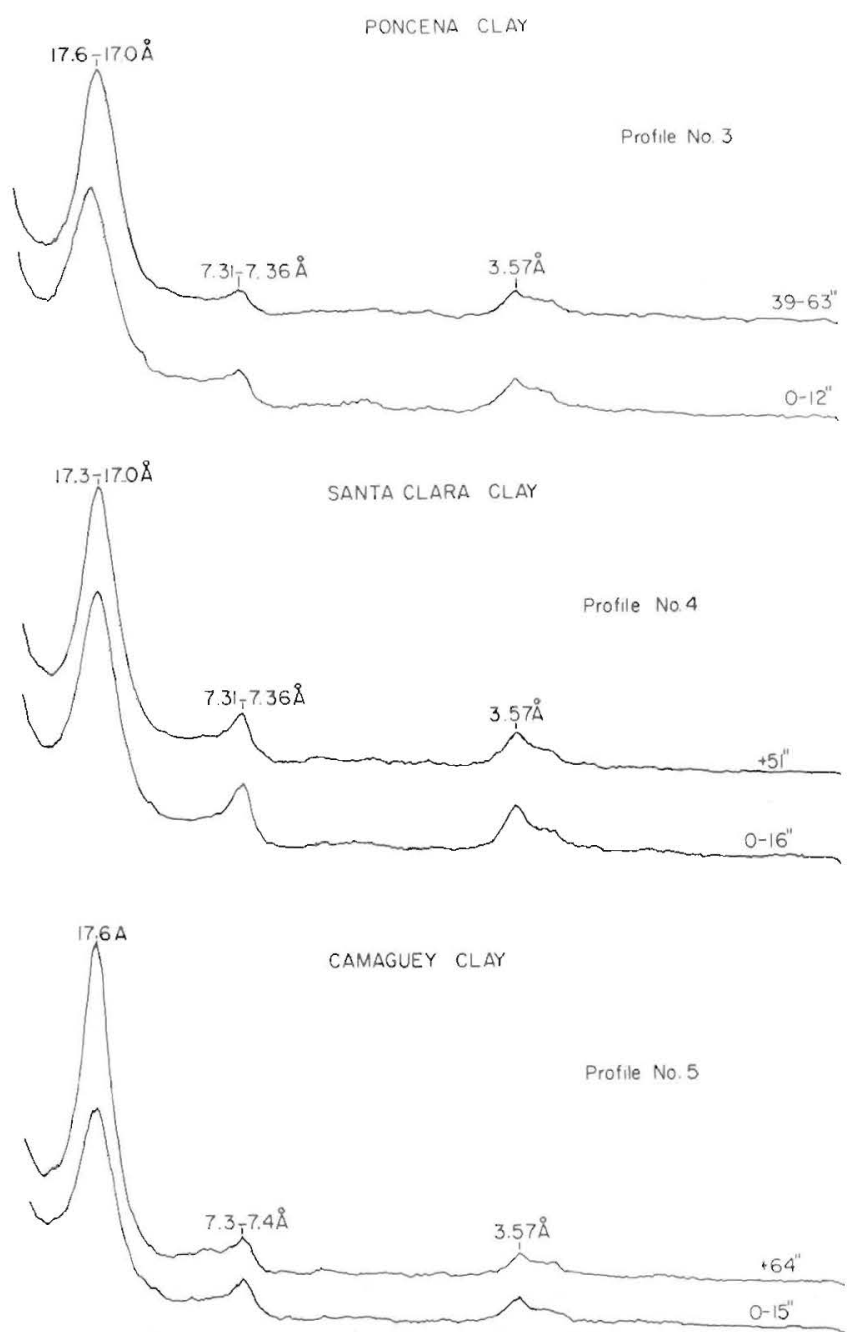

Frc. 2.-X-Ray diffraction pattern of the $<2$-micron fraction of the Poncena, Santa Clara, and Camagüey profiles.

of both has definitely been established by X-ray patterns presented in figure 1 . The exothermic peak, which occurs between $395^{\circ}$ and $420^{\circ} \mathrm{C}$, can be attributed to organic matter. It is interesting to compare the sharp, double, low temperature endotherms of the last three profiles with those of the Aguirre and Guánica soils. Since all the samples were saturated with the same cation, this variation is indicative of a compo- 


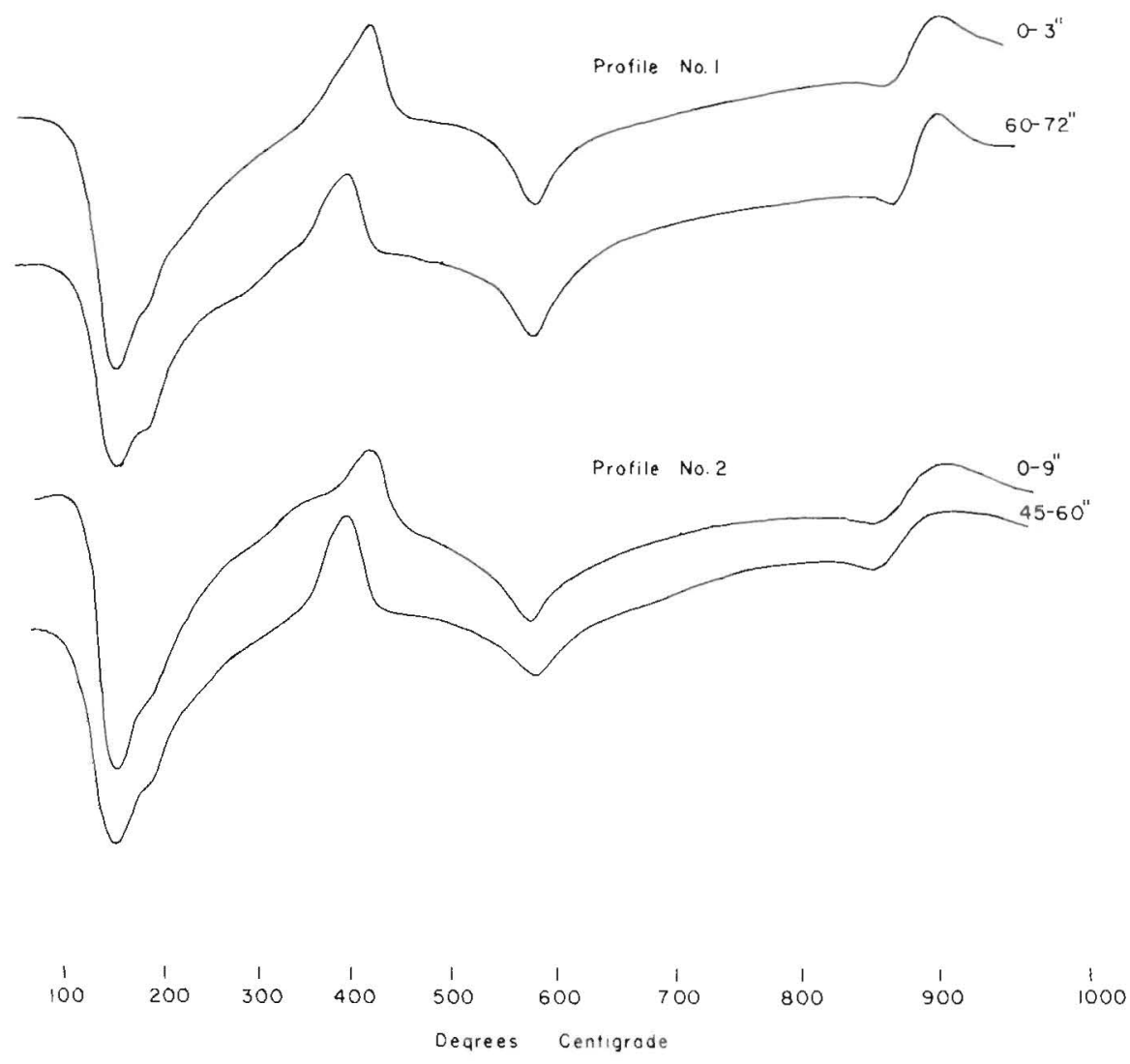

FIG. 3.-Differential thermal analyses of the <2-micron fraction of the Aguirre (No. 1) and Guánica (No. 2) profiles.

sitional difference in the clay mineral montmorillonite between the Aguirre and Guánica profiles and the Ponceña (No. 3), Santa Clara (No. 4), and Camagüey (No. 5). The sharp endothermic peak that occurs between $570^{\circ}$ and $580^{\circ} \mathrm{C}$, in the last three profiles (Nos. 3,4 , and 5), seems to be more related to the effect of kaolinite.

A very sharp exothermic peak is observed at a temperature between $365^{\circ}$ to $378^{\circ} \mathrm{C}$ in the last three profiles. Preliminary work using the method of Deb (3) for the removal of iron oxide, tenatively indicates that this is due to the presence of some form of iron which is crystallized at this temperature. According to Mackenzie (11) a sharp peak in the region 
D.T.A. Polferns
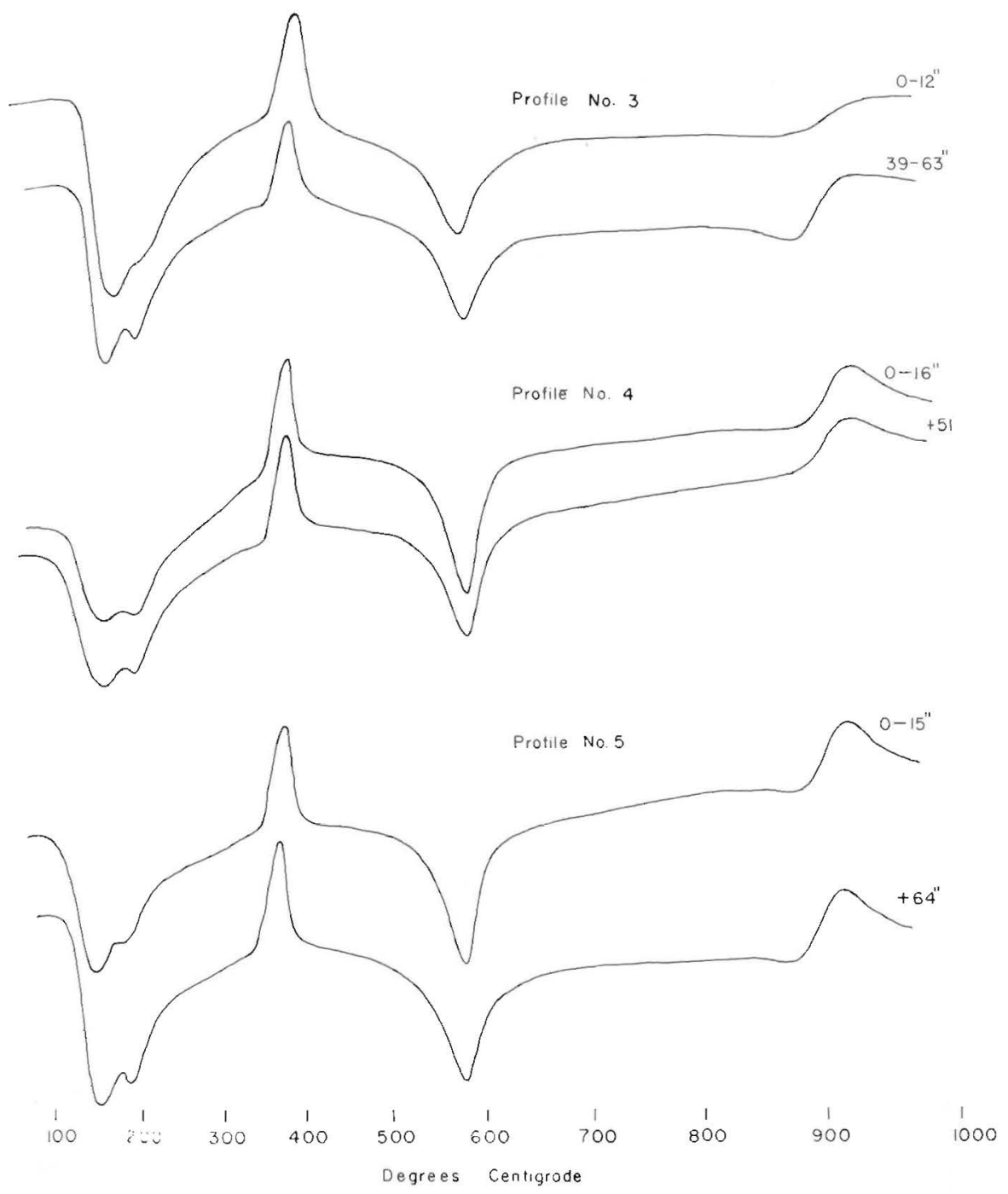

Fig. 4.-Differential thermal analyses of the $<2$-micron fraction of the Poncena (No. 3 ), Santa Clara (No. 4), and Camagüey (No. 5) profiles. 
of $350^{\circ} \mathrm{C}$, in the absence of organic matter, may be due to ferric oxide gel. Further work is needed to identify the material responsible for this exothermic peak.

It is concluded that the D.T.A. curves corroborate the findings of $\mathrm{X}$-ray studies, showing that montmorillonite dominates the clay fraction. However, the D.T.A. results, like the X-ray diffraction studies, point out a difference in the clay mineral montmorillonite found in the Aguirre and Guánica soils and that found in the other three soils. Further studies are needed to establish the nature of the difference in the montmorillonite found in the two groups of soils. Such findings may also help to explain some of the physical differences, particularly the higher maximum saturation values for the Aguirre and Guánica soils. Similarly, an explanation for the higher exchange capacities of these soils may be forthcoming.

\section{DISCUSSION}

Vertisols and Mollisols include most of the black clay soils of the world, which appear to have some fundamental properties in common. In looking at the overall picture of the morphological characteristics of the black or dark-colored soils of Puerto Rico, they appear to be similar to the other black soils of the world, including the soils of India (Regur), Morocco (Tirs), Africa (Black Cotton Soils), and the southern United States (Rendzina). In general, four of these five profiles have many of the characteristics of the Vertisols, while one profile has the characteristics of the Mollisols. The laboratory results should prove useful in conjunction with further field studies in the resolution of the classification of these soils. Based solely on the laboratory results and the profile descriptions, the Aguirre, Guánica, Ponceña, and Camagüey soils meet the requirements of Vertisols, while the Santa Clara soil meets the requirements of Mollisols. They are Typic Pelluderts (Camagüey), Udic Pellusterts (Aguirre, Guánica, and Ponceña), and Eutropeptic Rendolls (Santa Clara) (6). However, it might well be that some of these soils would be classified more properly as intergrades between those g 'eat soil groups and subgroups and some other closely related group or subrroup.

Emphasis was given in the study to the physico-chemical and mineralogical characteristics of these soils in order to evaluate their significance to agriculture. It is very important to determine the physical properties of the surface soil and subsoil before deciding on the productivity status of the soil in terms of plant growth. Plants require water and air in addition to nutrients for normal growth, which means that an abundance of nutrients alone does not make for a productive soil.

In order to maintain favorable water and air relationships, it is 
important that the pore space provide adequate water storage and at the same time provide good aeration. It was found that the amount of water adsorbed by the soils was high, but the pore spaces were small, as shown by the amount of water retained at low tension. This may be a limiting factor for good plant growth and especially for the development of a strong root system.

The results indicate that the Aguirre and Guánica profiles have some agricultural problems. Low hydraulic conductivity, a swelling type of clay mineral (montmorillonite), high clay content, fine internal porosity, and the presence of high amounts of exchangeable sodium and magnesium are among the properties which will influence the productivity of these soils. Difficulties may be encountered when these soils are subjected to drainage or reclamation. It has been emphasized by Baver (2) that the design of a drainage system is primarily dependent upon the hydraulic conductivity of the soil. The harmful effects of sodium on the physical properties of soils have been emphasized (17). Joffe and Zimmerman (5) found that a low Ca:Mg ratio behaved like a high $\mathrm{Na}$ content which is often harmful to normal plant growth.

Many plant nutrients are held in the soil as exchangeable ions and their availability to plants depends on exchange reactions. It was found that the exchange capacities of the Puerto Rico soils investigated are high, as shown in table 3 . Therefore, these soils have the ability to retain relatively large amounts of exchangeable plant nutrients; however, the question of availability of these nutrients remains open to question.

The Aguirre and Guánica soils have higher exchange capacities and are rather high in exchangeable sodium and magnesium with a small amount of potassium. In contrast the last three profiles are low in sodium, magnesium, and potassium. The X-ray diffraction and D.T.A. studies show that there is a difference in the montmorillonitic clay mineral present in these two groups, which may account for some of the variations between these two groups of soils.

There are many things to be explained, not only in relation to the morphological, physical, and chemical properties of the soils, but in relation to the nature of the clay mineral fraction of tropical soils. Relatively little is known still of the types of clay minerals which occur in Puerto Rico. In general, it was found that montmorillonite dominated the clay fraction of the soils studied. Many of the soil properties, such as plasticity, stickiness, swelling and shrinking upon wetting and drying, and exchange capacity, are dependent upon the clay mineral fraction of the soil.

It is expected that the observed relationships of morphological, physico-chemical, and mineralogical properties may help to clarify some of the agricultural problems of the dark-colored clay soils of Puerto Rico. 


\section{RESUMEN}

Los suelos que se estudiaron se caracterizan por tener una superficie de color negro o gris oscuro. Son pegajosos, plásticos y tienen una alta capacidad para hincharse y encogerse cuando se humedecen y resecan, respectivamente. Generalmente, la estructura del suelo en el horizonte superficial es de desarrollo moderado, pero se debilita cuando se profundiza. Los suelos se desarrollaron de una matriz calcárea.

Las descripciones morfológicas de algunos de los suelos oscuros arcillosos de Puerto Rico tienden a ser similares a las de los suelos negros u oscuros de los trópicos y de otras áreas incluyendo los de India (regur), Marruecos (tirs), Africa (black cotton) y del sur de los Estados Unidos de América (rendzina), clasificados ahora mayormente como Vertisols y Mollisols según el nuevo sistema de clasificación de suelos de los Estados Unidos.

De los análisis físicos se desprende que estos suelos tienen una conductividad hidráulica baja y un desagüe interno pobre. El análisis mecánico revela la naturaleza arcillosa de estos suelos. Los suelos acusan saturación hídrica y una alta porosidad en la que predominan los poros pequeños según se deduce de la alta cantidad de humedad que retienen a bajas tensiones.

Los análisis químicos indican que todos suelos son de reactión alcalina, con excepción del horizonte superficial del perfil del suelo Ponceña. El pH aumenta a medida que aumenta la profundidad.

Se encontró que el nivel de materia orgánica es generalmente alto en todos los suelos. Este nivel es especialmente alto en el caso del suelo Aguirre, lo que se atribuye al desagüe pobre que lo caracteriza.

Los perfiles de los suelos Aguirre y Guánica conticnen grandes cantidadas de sodio, calcio y magnesio intercambiables y relativamente pequeñas cantidades de potasio intercambiable. En contraste, los suelos Ponceña, Santa Clara y Camagüey contienen grandes cantidades de calcio intercambiable pero pequeñas de sodio, magnesio y potasio.

Los perfiles de los suelos Aguirre y Guánica acusan la mayor capacidad de intercambio tanto en los suelos tratados que quedaron libres de carbonato calizo como en los no tratados.

El cuarzo es el mineral predominante en la fracción de limo, pero hay pequeñas cantidades de feldespatos en todos los casos.

Los patrones de difracción de rayos X y las curvas de análisis térmico diferencial indican que la montmorillonita es el mineral predominante en la fracción arcillosa con pequeñas cantidades de caolinita y cuarzo. En la montmorillonita y la caolinita en los últimos tres perfiles se observa un mayor grado de cristalización según indican los picos más simétricos en sus patrones de difracción de rayos $\mathrm{X}$.

La difracción de rayos $\mathrm{X}$ en los suelos Aguirre y Guánica indica un minimo de intemperización. Los minerales en la fracción arcillosa de los suelos Ponceña y Camagüey revelan muy poca intemperización.

A base de los datos disponibles, se puede concluir que los suelos oscuros arcillosos de Puerto Rico llenan muchos de los requisitos de los grupos de suelos conocidos como Pellusterts, Pelluderts y Rendolls. Sin embargo, se requieren estudios adicionales para ubicarlos con mayor precisión dentro del esquema de clasificación de suelos desarrollado en los Estados Unidos, porque algunos de estos suelos pueden ser de naturaleza intermedia (intergrades) entre éstos y utros grupos de suelos relacionados.

\section{LITERATURE CITED}

1. Bal, D. V., Some aspects of the black cotton soil of the central Provinces, India, London, Thomas Murby and Co., Trans. Third Inter. Cong. of Soil Sci. 3: 154-7, 1935. 
2. Baver, L. D., Soil Physics, John Wiley \& Sons, Inc., New York, N.Y., 1956.

3. Deb, B. C., The estimation of free iron oxides in soils and clays and their removal, Jour. Soil Sci. 1: 212-20, 1950 .

4. Del Villar, E. H., The tirs of Morocco, Soil Sci. 57: 313-39, . 1944.

5. Joffe, J. S. and Zimmerman, M., Sodium, calcium, and magnesium ratios in the exchange complex, Soil Sci. Soc. Amer. Proc. 9: 51-5, 1944.

6. Kerr, P. F., Kulp, J. L., and Hamilton, P. R., Differential thermal analyses of reference clay mineral specimens, Reference Clay Mineral, A.P.I. Research Project 49, Columbia Univ. New York, 1951.

7. Kunze, G. W. and Templin, E. H., Houston black clay, the type grumusol: II. Mineralogical and chemical characterization, Soil Sci. Soc. Amer. Proc. 20: 91-6, 1956.

8. - and Oakes, H., Field and laboratory studies of the Lufkin soil, a Planosol, Soil Sci. Soc. Amer. Proc. 21: 330-5, 1957.

9. - Anomalies in the ethylene glycol solvation technique used in X-ray diffraction, Proc. Third Conf. on Clays and Clay Minerals, Natl. Res. Council Publ. 395: 88-93, 1955.

10. Lugo-López, M. A., Bartelli, C. J., and Abruña, F., An overview of the soils of Puerto Ricn: Classification, and physical, chemical and mineralogical properties, Agr. Exp. Sta. Univ. P.R. Publ. 79, 1973.

11. Mackenzie, R. C., Oxides and hydroxides of higher valency elements. In Differential Thermal Analysis, R. C. Mackenzie, ed., 270-9. Academic Press, London and New York, 1970.

12. Peech, M., Alexander, L. T., Dean, L. A., and Reed, J. F., Methods of soil analysis for soil-fertility investigations, USDA Circ. 757, 25 pp, 1947.

13. Simonson R. W., Morphology and classification of the regur soil of India, Jour. Soil Sci. 5: $275-388,1954$.

14. Soil Survey Staff, Soil Calssification: A Comprehensive System, 7th Approximation, USDA Soil Conservation Service, 265 pp, 1960.

15. Stephens, C. G., Comparative morphology and genetic relationships of certain Australian, North American, and European soils, J. Soil Sci. 1: 132-49, 1950.

16. Soil Survey Staff, Soil Survey Manual, USDA Handbook No. 18, 503 pp, 1951.

17. U.S. Salinity Laboratory Staff, Diagnosis and Improvement of Saline and Alkali Soils, L. A. Richards, ed., USDA Handbook No. 60, 160 pp, 1954.

18. Van der Merwe, C. R., Morphology of the South African black clays, London, Thomas Murby and Co., Trans. Third Inter. Cong. Soil Sci. 1: 301-3, 1935.

19. - Sub-Tropical black clays, Netherlands, Hoitsema Brothers, Trans. Fourth Int. Cong. Soil Sci. 2: 191-3, 1950. 